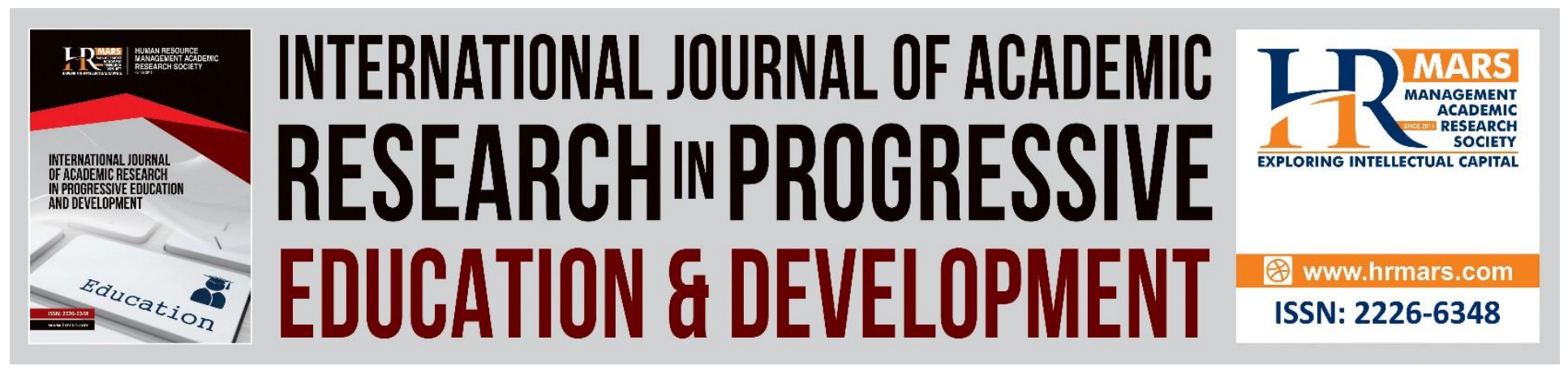

\title{
Observation Methods for Child Care Provider and Teacher's Pedagogy of Play
}

Loy Chee Luen, Nor Mashitah Mohd Radzi, Nordin Mamat, Sopia Md Yassin, Syahida Iryani Mohd Yusoff

To Link this Article: http://dx.doi.org/10.6007/IJARPED/v7-i3/4571

DOI: $10.6007 /$ IJARPED/v7-i3/4571

Received: 11 June 2018, Revised: 18 July 2018, Accepted: 23 July 2018

Published Online: 29 July 2018

In-Text Citation: (Luen, Radzi, Mamat, Yassin, \& Yusoff, 2018)

To Cite this Article: Luen, L. C., Radzi, N. M. M., Mamat, N., Yassin, S. M., \& Yusoff, S. I. M. (2018). Observation Methods for Child Care Provider and Teacher's Pedagogy of Play. International Journal of Academic Research in Progressive Education and Development, 7(3), 530-538.

Copyright: (c) 2018 The Author(s)

Published by Human Resource Management Academic Research Society (www.hrmars.com)

This article is published under the Creative Commons Attribution (CC BY 4.0) license. Anyone may reproduce, distribute, translate and create derivative works of this article (for both commercial and non-commercial purposes), subject to full attribution to the original publication and authors. The full terms of this license may be seen

at: http://creativecommons.org/licences/by/4.0/legalcode

\section{Vol. 7, No. 3, July 2018, Pg. 530 - 538}




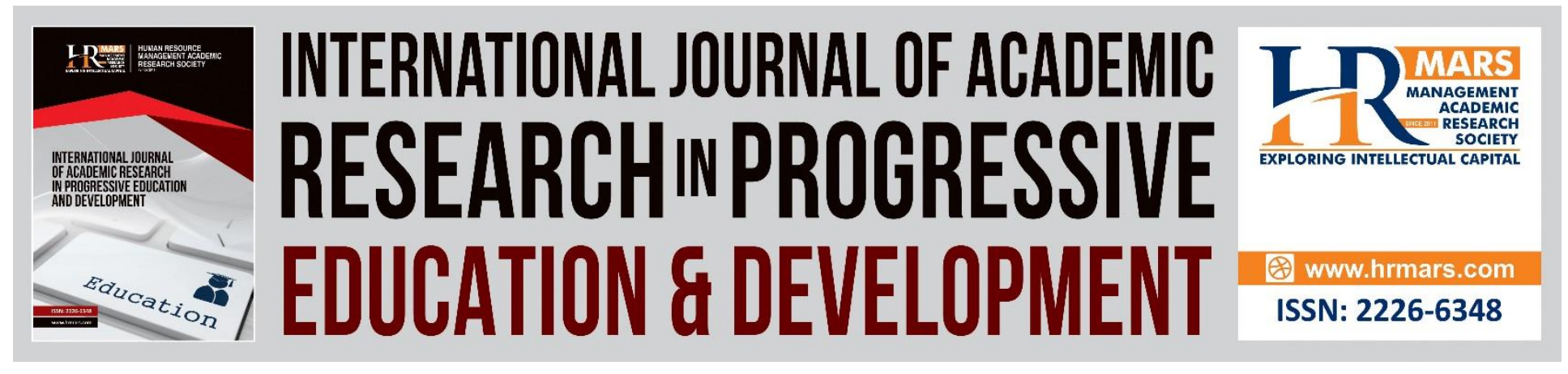

\title{
Observation Methods for Child Care Provider and Teacher's Pedagogy of Play
}

\author{
Loy Chee Luen
}

Department of Early Childhood Education, Faculty of Human Development, Universiti

Pendidikan Sultan Idris, Malaysia.

\author{
Nor Mashitah Mohd Radzi \\ Department of Early Childhood Education, Faculty of Human Development, Universiti \\ Pendidikan Sultan Idris, Malaysia.
}

Nordin Mamat

Department of Early Childhood Education, Faculty of Human Development, Universiti

Pendidikan Sultan Idris, Malaysia.

\section{Sopia Md Yassin}

National Child Development Research Centre, Universiti Pendidikan Sultan Idris, Malaysia.

\section{Syahida Iryani Mohd Yusoff}

National Child Development and Research Centre, Universiti Pendidikan Sultan Idris, Malaysia.

\begin{abstract}
This paper aims to identify observation method encompasses sampling criteria, observation instrument, validation and reliability observation instrument and procedure for child care provider and teacher's pedagogy of play in Project Determining Contributing Factors of Quality Early Childhood Care and Education (ECCE). Observation instrument and the guideline are prepared by the researchers to assess child care provider and teacher's pedagogy of play to achieve Standard of Quality Malaysian ECCE. Observation instruments for pedagogy of play were determined based on child care provider or teacher and child interaction; indoor and outdoor environment and pedagogy of play activities quality. The section of this instrument contains 4 levels of assessment namely Quality, Standard, Element and Indicator. The sample selection for observation suggested by agencies such as Ministry of Education; Department of National Unity and Integration, Prime Ministry Department; PERMATA Division, Prime Ministry Departmant; Ministry of Rural and Regional Development; non-governmental organizations and association
\end{abstract}


Vol. 7, No. 3, July 2018, E-ISSN: 2226-6348 @ 2018 HRMARS

based on the National Child Data Centre, Malaysia, PERMATA Q Marks Score, Malaysia, National Preschool Quality Standards, Malaysia, the achievement of Compliance Standard from Department and Ministry of Rural and Regional Development and and best practices proposed by associations. It is hoped that these process of observation method can identify the validation of observation method on pedagogy of play for selected child care provider in nursery and teacher in kindergarten in this project.

Keywords: Observation, Pedagogy of play, Child Care Provider, Teacher

\section{Introduction}

Observation method encompasses sampling criteria, observation instrument, validation instrument and observation prosedure are found in qualitative research methodology. According to Creswell (2014), Merriam and Tisdell (2016) and Palaiologou (2016), observation is the best way to collect the first hand data. Researchers as observer inside and outside the classroom scene observe and record the behavior of children, child care provider or teacher across enhanced focused provision pedagogy of play. Although the researchers follow the pedagogy or activities section of the child care provider or teacher, researchers do not influence their pedagogy of play strategies and process. Through observation, the researchers are able to gather evidence about pedagogy of play. In this study, the researchers applied non-participant observation based on child care provider or teacher and child interaction; indoor and outdoor environment and pedagogy of play activities for selected nursery and kindergarten based on the Standard of Quality Malaysian ECCE.

\section{Background}

Pedagogy of play in ECCE is important for the children's holistic development, which encompasses socio-emotional, language, physical, cognitive, creativity and spiritual. Children are encouraged to explore, experiment and experience in pedagogy of play activities. They need to interact with other children or child care provider or teachers. They also need a safe and fun indoor and outdoor environment towards pedagogy of play (PERMATA, 2013; KPM, 2016). Nowadays, various government agencies such as Ministry of Education; Department of National Unity and Integration, Prime Ministry Department; PERMATA Division, Prime Ministry Department; Ministry of Rural and Regional Development; Terengganu Family Development Foundation, Terengganu Islamic Foundation and Perak Islamic Department had provided ECCE program. Besides, non-governmental organizations, associations and private sectors also concerned about the quality of ECCE program. In this study, observation method encompasses levels of assessment namely Quality, Standard, Element and Indicator that involves selected child care provider in nursery and teacher in kindergarten for Determining Contributing Factors of Quality ECCE.

\section{Problem Statement}

The problem encountered by the data collection of observation method involving multiple data is incomplete and only in general and individually (Podmore \& Luff, 2012; Merriam and Tisdell, 2016; Palaiologou, 2016). Furthermore, the data obtained are also not comparable, depth and breadth in contains levels of assessment includes Quality, Standard, Element and Indicator. However, if the observation data analysis is organise in detail, it is hoped that it will gain high 
Vol. 7, No. 3, July 2018, E-ISSN: 2226-6348 @ 2018 HRMARS

validity of observation method against child care provider in nursery and teachers kindergarten. In this research, indicator namely Working Towards, Achieve Standard and Exceeding Standard use to assess child care provider or teacher pedagogy of play. For each Indicator, there is a record space for the record of the investigator. Each indicator also has a guide for the researcher to obtain the assessment information either to observe, interview and to check the related document. Data can also be interpreted properly and well organized. Sample diversity contributes to data input variation that can provide enough insights to identify Determining Contributing Factors of Quality ECCE.

\section{Literature Review}

The literature review includes observation method for pedagogy of play; ECCE pedagogy of play encompasses child care provider or teacher and child interaction, indoor and outdoor play environment and pedagogy of play activities.

\section{Observation Method for Pedagogy of Play}

Observation methods used in this research are observation instrument to identify 3 rating levels namely Working Towards, Achieve Standard and Exceeding Standard, interview and to check the related document, such as lesson plans and module. Non-participant observation is one of the observation methods. This method refers to a full observation against child care provider or teacher's pedagogy strategies and process. This type of observation requires observers to choose the right nursey and kindergarten to observe. Observation sites should give the observer the maximum possible opportunity for observers to observe the pedagogy of play (Pianta, Hamre \& Mintz, 2012; Podmore \& Luff, 2012, Merriam \& Tisdell, 2016). Observation can be done with the equipment such as recording equipment including tapes, video and cameras. Observation instrument in this research are adapted from National Child Data Centre, Malaysia launched in the year 2016; PERMATA Q Marks Score from PERMATA Division, Prime Ministry Department; National Preschool Quality Standards from Ministry of Education, Malaysia; National Association for the Education of Young Children, NAEYC (2015); Australian Children's Education and Care Quality Authority ACECQA (2012) and the researchers had applied non-participant observation method.

\section{ECCE Pedagogy of Play}

Pedagogy of play enhances children's holistic development. Play is a natural activity and a need for every child. Through pedagogy of play activities, children are free to explore because they are creative and have high imagination. Children get knowledge and have a chance to learn the skills through hands-on experiences. Child care provider and teacher should play a major role in the teacher and child interaction (Wood, 2013; Norsita \& Zainal 2014). The attractive, clean, comfortable and safe play environment are important to conduct the pedagogy of play and enhance the development of children.

\section{Child Care Provider or Teacher and Child Interaction}

Teachers articulate children's creative thinking through teacher and child interactions such as divergent questioning techniques, encouraging students and giving praise and appreciation. Teacher and child interaction in the classroom are complementary. Children must be guided to 
Vol. 7, No. 3, July 2018, E-ISSN: 2226-6348 @ 2018 HRMARS

reach meaningful interactions and build sensitive and responsive relationships between teacher and children (Norsita \& Zainal, 2014; Blatchford, Pellegrini \& Baines 2016). In this research, teacher and child interaction included (i) showing respect and fairness that are divided into interactions with children, engaging in meaningful interactions and helping to feel safe, confident and empowered; and (ii) build sensitive and responsive relationships that are divided into encouragement to collaborate, conduct behavior and respect the rights of children.

\section{Indoor and Outdoor Play Environment}

The role of child care provider or teacher needs to be strengthened by providing space include indoor and outdoor play environment or stimulus for children in order to play, prepare pedagogy's tools and materials for children to develop their knowledge through play and child care provider or teacher become an effective observer for children while playing (Palaiologou, 2016; Zakiah, Azlina \& Yeo, 2013). In this research, indoor and outdoor environments included (i) the needs of children divided into space layouts, tools and materials, classroom arrangements, suitability of outdoor playground equipment and their special needs to explore, experiment and experience; (ii) teaching learning space and teaching aids that are divided into the adequacy of the equipment and materials as well as the relevance of access, equipment and materials; and (iii) the arrangement of tools, spaces and materials such as the suitability of space, learning materials, monitoring sites and the comfort of the baby's intake.

\section{Pedagogy of Play Activities}

Pedagogy of play activities provide children with opportunities to explore and experience. Children play without realizing they are actually learning something from the play activities. Social play, manipulative play and creative play activities can create a great emotional Quotient as well as stimulate their intelligent quotient and creative quotient (Beaty, 2014; Palaiologou, 2016; Loy, Nordin, Nor Mashitah \& Sopia, 2017; Nordin, Nor Mashitah, Loy \& Sopia, 2017; ). In this research, learning activities included (i) children's learning that is divided into the effectiveness of learning activities as well as support, encouragement and guidance; (ii) focus, active and reflective in the implementation of activities divided into the use of child information in the implementation of activities and involvement of children; (iii) parenting and education strategies that are divided into the skills of using the child's interests and the understanding of the baby's needs; and (iv) meaningful learning that is divided into interest and involvement of children as well as understanding children with language diversity.

\section{Observation Method}

Observation method in this reseach about child care provider and teacher's pedagogy of play encompassess (i) sampling criteria (ii) observation instrument (iii) validity and reliability instrument and (iv) observation prosedure.

\section{Sampling Criteria}

The selection of sample in this research can represent the variable of the target population and has the same characteristics in nursey (TASKA) and kindergarten (TADIKA). 


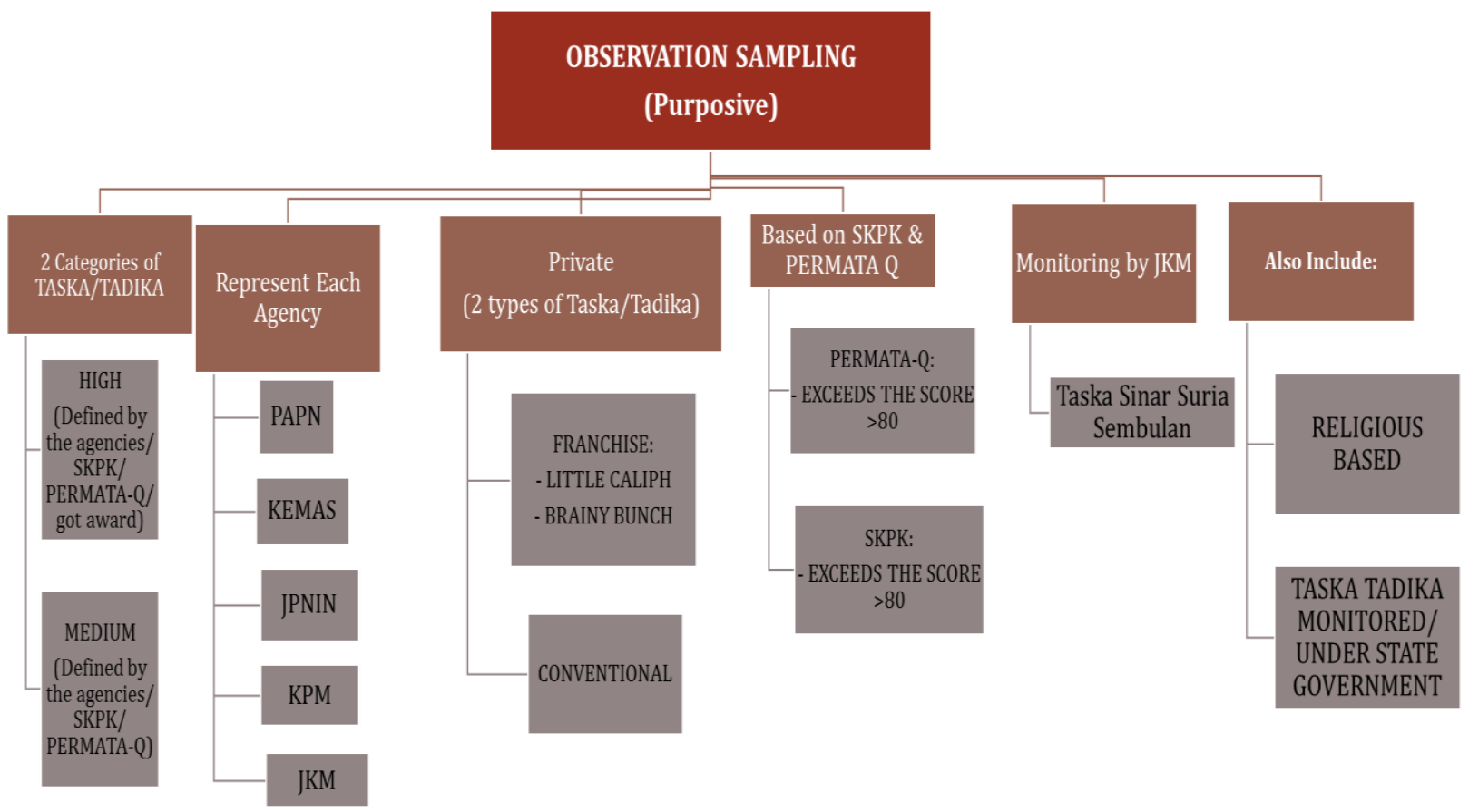

Chart 2 shows the sample selection for observation suggested by agencies such as Ministry of Education; Department of National Unity and Integration, Prime Ministry Department; PERMATA Division, Prime Ministry Department; Ministry of Rural and Regional Development; nongovernmental organizations and associations based on the National Child Data Centre, Malaysia, PERMATA Q Marks Score, Malaysia, National Preschool Quality Standards (SKPK), Malaysia, the achievement of Compliance Standard from Department and Ministry of Rural and Regional Development and and best practices pedagogy of play proposed by associations.

Evaluation and monitoring of internal quality by ministry encompassess Ministry of Education; Department of National Unity and Integration, Prime Ministry Department; PERMATA Division, Prime Ministry; Department and Ministry of Rural and Regional Development covering aspects of facilities, staff, teaching, finance and management.

Compliance Standard from Department and Ministry of Rural and Regional Development covering (i) Quality Improvement Standard and (ii) Tasks Inspection Report encompassess demographics, building or premises, space, cleanliness, equipment, teaching tools, furniture, pedagogy's activity, programs, food menu and nutrition, relationships and interactions, administration and management, ratio of child care provider or teacher and children.

PERMATA Q Marks Score PERMATA Division, Prime Ministry Department covering standards of (i) exceeding the threshold level of PERMATA-Q (> 80); (ii) Surpassing threshold level approval per Standard Quality (SQ): SQ1: Routine Practice and Child Care (85\%) SQ2: Learning and Assessment (85\%) SQ3: (85\%) SQ4: Physical Security and Learning Resources (80\%) SQ5: Human Resources (75\%) SQ6: Management (70\%). 
INTERNATIONAL JOURNAL OF ACADEMIC RESEARCH IN PROGRESSIVE EDUCATION AND DEVELOPMENT

Vol. 7, No. 3, July 2018, E-ISSN: 2226-6348 @ 2018 HRMARS

Non-governmental organizations and association encompassess nursery and kindergartern nominated by association covering best practices proposed by associations in the aspects of convenience, pedagogy strategies, adimnstration and management, get high demand from parents and fees.

\section{Observation Intrument}

Observation instrument for this reseach are adapted from National Child Data Centre, Malaysia; PERMATA Q Marks Score, Malaysia; National Preschool Quality Standards, Malaysia; National Association for the Education of Young Children, NAEYC (2015), Australian Children's Education and Care Quality Authority ACECQA (2012). The purpose of observation instruction and the National Child Care and Assessment Quality Assessment Guide is to ensure the factors that contribute to the quality of care and education of children in Malaysia. Researchers using this instrument need to: (i) provide assessment and visits, (ii) record observations and evidence (documents) during observation and assessment and (iii) determine the rating and provide observation and assessment reports after the visit.

The use of this instrument also includes the provision of assessment and rating process and complete observation reports. The National Instructional and Children's Quality Assessment Guide covers (i) details of observations and assessments, (ii) the list of benchmarks for each indicator followed by an entry space to record observation and assessment results and (iii) observation and assessment guides.

\section{Validity and Reliability of the Intrument}

The main features of determining the suitability and usability of an instrument are validity and reliability. The purpose of the instrument's validity is to confirm appropriateness, truthfulness, meaningfulness and usefulness of observation instruments in order to determine the contributing factors of quality ECCE. On the other hand, the purpose of reliability is to determine whether the measure provides the same answer when it is used to measure the same concepts to the same sample. Reliability in qualitative data for this research relates to researchers' observation about child care provider or teacher and child interaction; indoor and outdoor environment and pedagogy of play activities' quality.

Pilot study had been conducted to obtain validity and reliability for the observation instrument. The results of observation together with the field notes are presented to the project advisor and expert in ECCE for review to ensure the alignment between the observation results and the objectives. The opinion of all experts has been recorded in determining the selection of these observation items. As a result of this pilot study, the researchers obtained the consent of the project principle to perform a real field work for this research.

\section{Observation Prosedures}

The researchers should know how to use observation instrument to record observations and assessments regarding the pedagogy of play. This instrument contains a section where the researchers must complete the observation and assessment process. The quality section of this document contains 4 levels of assessment namely Quality, Standard, Element and Indicator. Each Indicator has 3 rating levels includes Working Towards, Meeting Standard and Exceeding Standard. For each Indicator, there is a space for the observers to record. Each indicator also has 
Vol. 7, No. 3, July 2018, E-ISSN: 2226-6348 @ 2018 HRMARS

a guide for the researchers to obtain assessment information whether to make observation, interview or check the relevant documents.

Before the observation, the researchers need to have planning. Each pedagogy of play observation section must have a specific purpose, focused and must be recorded. The researchers should complete the observation and assessment details section encompassess nursery or kindergarten information; the name of child care provider and teacher; the name of the observer; the date and time of observation and assessment; the researcher needs to record the certain standards or elements or indicators on the observation, interviews and analysis of the relevant documents.

During the observation, the reseachers observe but did not participate in what is happening in pedagogy of play setting. So, the observation of the pedagogy strategies and process is more detailed, clear, more valid and credible for the research findings. The researchers should be noted of certain standards or elements or indicators on the observation, interviews and analysis of the documents. The researchers also need to record audio or video and take photos to obtain evidence and references for report writing. Information about pedagogy of play obtained from observation is either can or cannot be an important references in the research. The researchers must ensure that the information obtained from the observations is from the child care provider or teacher to be studied.

After the observation, the researchers need to write a report and decide whether they have achieved the quality or standard or element or indicator. Researchers should also report best practices and barriers to the quality of care and education of children in completing the report regarding to the rating level that shown in this instrument as either Working Towards, Meeting Standard or Exceeding Standard for selected nursery and kindergatern in this research.

\section{Conclusion}

Observation instrument and the guideline prepared for the researchers to assess child care provider and teacher can assess quality, standard, element and indicator in pedagogy of play. Indicator rating levels namely Working Towards, Meeting Standard and Exceeding Standard can determine quality of child care provider in nursery and teacher's pedagogy of play in kindergarten. The right sampling criteria an the systematic process of observation method can produce a desired result for Project Determining Contributing Factors of Quality ECCE.

\section{Acknowledgement}

This part of the research "development of a comprehensive and integrated model of quality malaysian early childhood care and education-project 3/tla: determining contributing factors of quality ecce" (2015-0024-106-04-3) is funded by ministry of finance through ministry of education malaysia. Special appreciation is also dedicated to national child development research centre universiti pendidikan sultan idris, malaysia for giving us the opportunity to carry out this research project. 
INTERNATIONAL JOURNAL OF ACADEMIC RESEARCH IN PROGRESSIVE EDUCATION AND

DEVELOPMENT

Vol. 7, No. 3, July 2018, E-ISSN: 2226-6348 @ 2018 HRMARS

\section{Corresponding Author}

Dr. Loy Chee Luen

Associate Professor

Department of Early Childhood Education

Faculty of Human Development

Universiti Pendidikan Sultan Idris

Perak, Malaysia

Email: loy.cl@fpm.upsi.edu.my

\section{References}

Australian Children's Education and Care Quality Authority, ACECQA. (2012). National Quality Standard Assessment and Rating Instrument. Australia: ACECQA

Bahagian Pendidikan Awal Kanak-kanak (PERMATA). (2013). Kurikulum PERMATA Negara: Asuhan dan Didikan Awal Kanak-kanak 0-4 Tahun. Malaysia: Jabatan Perdana Menteri.

Beaty, J.J. (2016). Skills for Preschool Teachers. United Kingdom: Pearson Education.

Beaty, J.J. (2014). Preschool Appropriate Practices: Environment, Curriculum and Development. United States: Cengage Learning.

Blatchford, P., Pellegrini, A.D. \& Baines, Ed. (2016). The Child at School: Interactions with Peers and Teachers. London: Routledge.

Creswell, J.W. (2014). Research Design: Qualitative, Quantitative, and Mixed Methods Approaches. London: Sage Publications.

Kementerian Pendidikan Malaysia. (2016). Kurikulum Standard Prasekolah Kebangsaan (KSPK). Malaysia: Bahagian Pembangunan Kurikulum, Kementerian Pendidikan Malaysia.

Luen, L. C., Mamat, N., Radzi, N. M. M. \& Yassi, S.M. (2017). Observation Instrument to Evaluate Early Childhood Educator's Teaching Strategies using Creative Arts. International Journal of Academic Research in Business and Social Sciences. Volume 7, Number 4. April 2017. 870-880.

Merriam, S. B. \& Tisdell, E.J. (2016). Qualitative Research: A Guide to Design and Implementation. United States: Jossey-Bass.

National Association for the Education of Young Children, NAEYC. (2015). Program Standards and Accreditation Criteria \& Guidance for Assessment. Washington: NAEYC.

Palaiologou, I. (2016). Child Observation: A Guide for Students of Early Childhood. United Kingdom: SAGE.

Pianta R.C., Hamre, B.K., \& Mintz S. (2012). Classroom Assessment Scoring Wystem: Secondary Manual. Charlottesville, VA: Teachstone.

Podmore, V.N. \& Luff, P. (2012). Observation: Origins and Approaches in Early Childhood: Origins and Approaches. United Kingdom: Open University Press.

Wood, E. (2013). Play, Learning and the Early Childhood Curriculum. London: SAGE Publications. 